\title{
Growth and Production of Crambe Submitted to Doses of Nitrogen and Potassium
}

\author{
Ramara Sena de Souza1, Lúcia Helena Garófalo Chaves ${ }^{1 *}$, Josely Dantas Fernandes², \\ Ana Carolina Feitosa de Vasconcelos ${ }^{1}$ \\ ${ }^{1}$ Federal University of Campina Grande, Campina Grande, Brazil \\ ${ }^{2}$ State University of Paraiba, Campus II, Lagoa Seca, Brazil \\ Email: "Ihgarofalo@hotmail.com
}

Received 23 August 2015; accepted 5 January 2016; published 8 January 2016

Copyright (C) 2016 by authors and Scientific Research Publishing Inc.

This work is licensed under the Creative Commons Attribution International License (CC BY). http://creativecommons.org/licenses/by/4.0/

c) (i) Open Access

\section{Abstract}

The dependence on non-renewable fuels of countries around the world increased the interest for the gradual replacement of fossil fuels with renewable ones. Thus, several development programs for the use of renewable sources for power generation have been created and, in this perspective, biofuels have been highlighted. Crambe is an alternative crop for the production of biodiesel due to its rusticity, precocity, high oil content and adaptability to different climates. Optimum management practices of fertilizer use in crambe cultivation are little known and there are no specific recommendations for its fertilization. Therefore, the objective of this research was to study the effects of mineral fertilizers concerning the nitrogen and potassium elements in the growth and production of crambe. The experiment was installed in a greenhouse, with a completely randomized design. Nitrogen doses used were 30, 60, 90 and $120 \mathrm{~kg} \cdot \mathrm{ha}^{-1}$ and 50, 75, 100 to $125 \mathrm{~kg} \cdot \mathrm{ha}^{-1}$ for potassium. The increase in production was directly proportional to the increase in nitrogen levels. The potassium doses did not cause significant effect on the growth of crambe.

\section{Keywords}

Biofuels, Fertilization, Crambe abyssinica, N, K

\section{Introduction}

The dependence on non-renewable fuels of countries around the world increased the interest for the gradual

${ }^{*}$ Corresponding author.

How to cite this paper: de Souza, R.S., Chaves, L.H.G., Fernandes, J.D. and de Vasconcelos, A.C.F. (2016) Growth and Production of Crambe Submitted to Doses of Nitrogen and Potassium. American Journal of Plant Sciences, 7, 8-16. 
replacement of fossil fuels with renewable ones, which was mainly with the oil crises in the 70s and 90s. At this time, it was made the proposition to the gradual substitution of fossil fuels by renewable ones in discussion forums, as well as with the creation of various programs for the development and use of renewable resources for power generation.

Nowadays the increasing use of fuels from non-renewable sources is seen as an unsustainable way of life, with environmental costs ever higher. [1] [2], each passing year the consumption of petroleum-based fuels increases and hence there is an increase in air pollution.

In this scenario, biofuels reach great importance because there are still no renewable alternatives with suitable technological development and economic viability sufficient to serve the purpose of transport [3].

The crops that are grown for biofuels are considered alternative economic sources and environmentally viable. However, the use of a culture for the biofuel generation depends on aspects defined for agronomic factors, such as oil content, productivity, production system and the crop cycle.

Therefore, it is believed that the Crambe abyssinica Hochst has great potential to constitute a raw material for biodiesel [4]. The crambe is an oilseed crop belonging to the Brassicaceae family, and there are about thirty species of this crop. However, the species cultivated on a large scale is Crambe abyssinica Hochst, also known as Abyssinian Kale [5].

This oilseed has become quite interesting option to present advantages as precocity, rusticity, good tolerance to climatic variations, low production cost and productivity between 1000 and $1500 \mathrm{~kg} \cdot \mathrm{ha}^{-1}$, greater oil production in relation to crops such as sunflower (Helianthus annuus), oil seed radish (Raphanus sativus L), canola (Brassica napus L) and jatropha (Jatropha curcas L), among others. In addition, crambe does not compete with crops intended for food production, making its cultivation for biofuel production feasible [6] [7].

Proper management fertilization of crambe still constitutes a major problem for the cultivation of this crop, since the information about fertilization of crambe is little known and there are no specific recommendations for this culture.

Therefore, due to the mentioned facts, and especially to represent a new option cultivation for semi-arid and sub-humid lands areas of the Brazilian Northeast, the aim of this work was to study the effects of the use of mineral fertilizers, referring to nitrogen elements $(\mathrm{N})$ and potassium $(\mathrm{K})$, on growth and yield of crambe.

\section{Material and Methods}

The experiment was carried out in a greenhouse located at the Academic Unit of Agricultural Engineering (UAEAg), Federal University of Campina Grande, Paraiba State.

Samples of soil (Quartzipsamment) from the city of Campina Grande were used as substrate. The samples were collected from the surface layer $(0-20 \mathrm{~cm})$ and, after being air dried and passed through a sieve opening of $2 \mathrm{~mm}$ mesh, were subjected to physical and chemical characterization, according to the methodology described by [8]. The results were the following: $\mathrm{pH}\left(\mathrm{H}_{2} \mathrm{O}\right)=7.1 ; \mathrm{Ca}=1.92 \mathrm{cmol}_{\mathrm{c}} \mathrm{kg}^{-1} ; \mathrm{Mg}=1.44 \mathrm{cmol}_{\mathrm{c}} \mathrm{kg}^{-1} ; \mathrm{Na}$ $=0.16 \mathrm{cmol}_{\mathrm{C}} \mathrm{kg}^{-1} ; \mathrm{K}=0.19 \mathrm{cmol}_{\mathrm{C}} \mathrm{kg}^{-1} ; \mathrm{H}=0.0 \mathrm{cmol}_{\mathrm{C}} \mathrm{kg}^{-1} ; \mathrm{Al}=0.0 \mathrm{cmol}_{\mathrm{C}} \mathrm{kg}^{-1} ; \mathrm{OM}=4.8 \mathrm{~g} \cdot \mathrm{kg}^{-1} ; \mathrm{P}=14.3$ $\mathrm{mg} \cdot \mathrm{dm}^{-3}$; sand $=874.0 \mathrm{~g} \cdot \mathrm{kg}^{-1}$; silt $=50.5 \mathrm{~g} \cdot \mathrm{kg}^{-1}$; clay $=75.5 \mathrm{~g} \cdot \mathrm{kg}^{-1}$. According to these results, the soil was classified as loamy sandy.

The experiment was carried out in a completely randomized design (CRD) following a factorial $4 \times 4+1$, with three repetitions, totaling 51 experimental units. The treatments resulted from the combination of four nitrogen rates (30, 60, 90, $120 \mathrm{~kg} \mathrm{~N} \mathrm{ha}^{-1}$ ) using urea as a source of $\mathrm{N}$; four potassium rates (50; 75; 100; $125 \mathrm{~kg} \mathrm{~K}_{2} \mathrm{O} \mathrm{ha}^{-1}$ ) using potassium chloride as a source of $\mathrm{K}_{2} \mathrm{O}$ and a control $\left(0 \mathrm{~g} \cdot \mathrm{kg}^{-1}\right.$ of $\mathrm{N}$ and $\left.\mathrm{K}\right)$.

Each experimental unit consisted of polyethylene pot filled with $20 \mathrm{~kg}$ of soil, where seven seeds were sown crambe, cultivate FMS Brilhante, from the Mato Grosso do Sul Foundation. Fifteen days after sowing was done the cutting of plants, remaining two plants per pot.

Potassium fertilization was fully applied in foundation, with the doses corresponding to the potassium treatments. After the incorporation of the fertilizer and seeding, soil irrigation was performed until field capacity, which was maintained throughout the experiment. Nitrogen fertilization was performed once shortly after the initial cut of the plants.

The variables analyzed during the plant development cycle were: plant height, measured in centimeters every thirty days; the stem diameter, measured in millimeters, using a digital pachymeter at 60 days after seeding (DAS); and the number of branches per plant which was determined at 60 DAS, counting all branches of each 
plant in the experimental units. Plants were harvested at 90 days after sowing, which corresponds to the end of the crop cycle.

The variables of production analyzed were the following. The total dry biomass, obtained through drying of the fresh parts of the plant in an air forced circulation stove, at a temperature of $60^{\circ} \mathrm{C}$ until constant weight. The number of grains per plant was obtained by manual threshing and by counting the number of grains of each plant. The thousand grain weight was determined by weighing 1000 grains.

The results were submitted to analysis of variance, using the SISVAR-ESAL software [9]. The type of regression used was orthogonal polynomial, since the factors were quantitative.

\section{Results and Discussion}

The coefficient of variation for the following variables presented medium dispersion: height of plants at 30 DAS (17.10) and at 60 DAS (13.00); stem diameter (10.11) and number of branches (17.84). On the other hand, the coefficient of variation for plant height at 90 DAS presented low dispersion (8.71), according to [10].

The use of nitrogen in fertilization influenced significantly only the number of branches at the level of $1 \%$ probability, corroborating with [11] which found no response to nitrogen for the plant height when this nutrient was applied in coverage. However, [12] observed that the nitrogen fertilization influenced the development of crambe plants.

The number of branches was directly proportional to increase in nitrogen levels, independent of potassium application (Figure 1). Plants submitted to the higher dose of $N\left(120 \mathrm{~kg} \cdot \mathrm{ha}^{-1}\right)$ and to the dose of $30 \mathrm{~kg} \cdot \mathrm{ha}^{-1} \mathrm{pre}-$ sented an average number of branches per plant equal to 69 and 45, respectively (Figure 1).

Through the regression analysis it was observed that the interaction of nitrogen applied in conjunction with the doses 50 and $100 \mathrm{~kg} \cdot \mathrm{ha}^{-1}$ of potassium was significant at $1 \%$ probability, presenting the linear trend, as presented in Figure 2. Probably, by observing the overlap of these lines, we can figure out that there was no difference in NR plants when fertilized with 50 and $100 \mathrm{~kg} \cdot \mathrm{ha}^{-1}$ potassium.

The application of potassium doses in crambe cultivation had no significant effect on the variables. Similar results were reported by [11] that also found no significant difference for the $\mathrm{K}_{2} \mathrm{O}$ application in crambe.

Potassium is a key element for most biological processes in a plant and when it is not available at the lowest dose, it can reduce the development of the crop and consequently its productivity [13] [14]. Therefore, it can be said that the quantity of the element present in the soil were sufficient for the nutritional requirements of the culture, and there was no optimization of the cultivation as according to the increased levels of this macronutrient.

Comparing the treatments that received doses of $\mathrm{N}$ and $\mathrm{K}$ with the control (Control vs Factor), there was significance at the $1 \%$ level of probability for stem diameter values and the number of branches.

The diameter of the plants subjected to higher $\mathrm{N}$ and $\mathrm{K}\left(\mathrm{N}_{4} \mathrm{~K}_{4}\right)$ reached measurements up $11.85 \mathrm{~mm}$, while for the control the maximum measurements were $8.15 \mathrm{~mm}$. Therefore, there was an increase of $45.40 \%$ in the diameter of crambe plants.

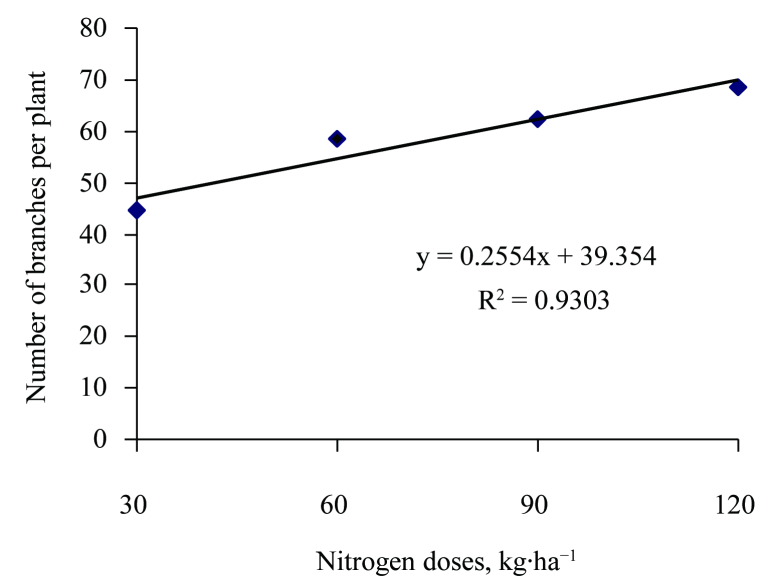

Figure 1. Number of branches of crambe according to the $\mathrm{N}$ rates. 
Similar results were reported by [15], who also found increased measurement of these parameters in relation to the control according to the doses of NPK. However, [16] found no statistical differences in the results when evaluating doses of 100, 200, $300 \mathrm{~kg} \cdot \mathrm{ha}^{-1}$ of NPK 07-24-24 formulated comparing with the control in crambe.

The coefficient of variation for number of grains per plant presented medium dispersion (12.17), while thousand grain biomass and total dry biomass presented a coefficient of variation with low dispersion (8.18 and 8.65, respectively), according to [10].

The number of grains per plant (NGP) and total dry biomass (TDB) varied significantly at $1 \%$ probability according to the increasing doses of nitrogen applied to experimental units (Figure 3).

Plants submitted to treatments with the highest nitrogen dose $\left(120 \mathrm{~kg} \cdot \mathrm{ha}^{-1}\right)$ produced an average of 566 grains, while those ones grown with only $30 \mathrm{~kg} \cdot \mathrm{ha}^{-1}$ of nitrogen had an average of about 254 grains, which is equivalent to an increase of $122.83 \%$. This fact disagreed with [17] when it states that the productivity of crambe grains presented no significant differences in fertilization arrangements. In Figure 3(a), the trend of this variable by using the transformed data is presented.

The same effect can be observed for the production of dry biomass of plants, which increased by 35\% (Figure 3(b)), confirming [18] who observed that treatment with sowing fertilization in crambe showed higher production of dry biomass in relation to the treatment without fertilization, although statistically the treatments did not differ.

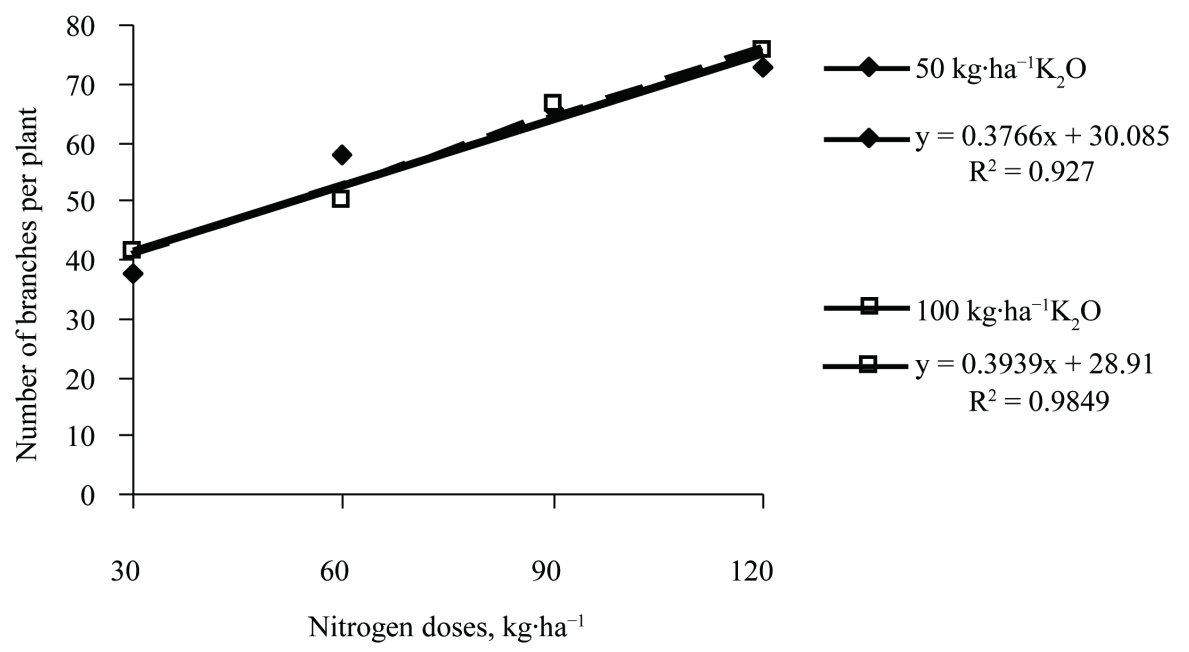

Figure 2. Number of crambe branches according to $\mathrm{N}$ rates and considering the application of 50 and $100 \mathrm{~kg} \cdot \mathrm{ha}^{-1}$ of $\mathrm{K}_{\text {. }}$

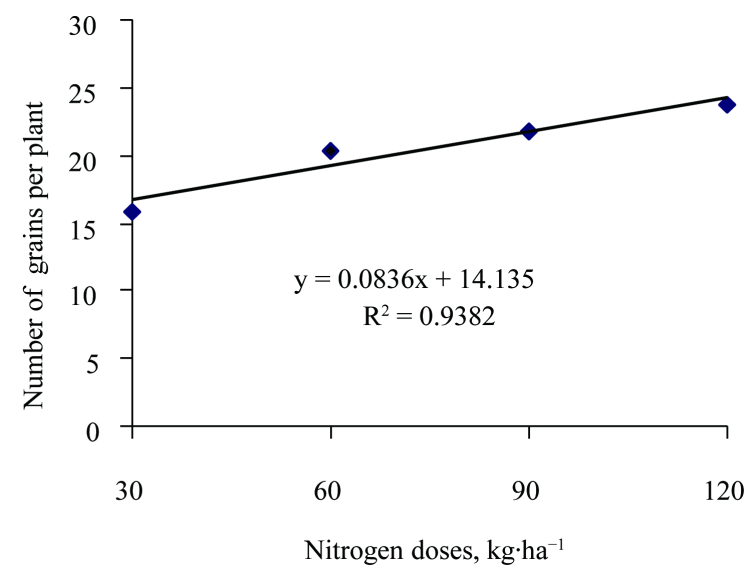

(a)

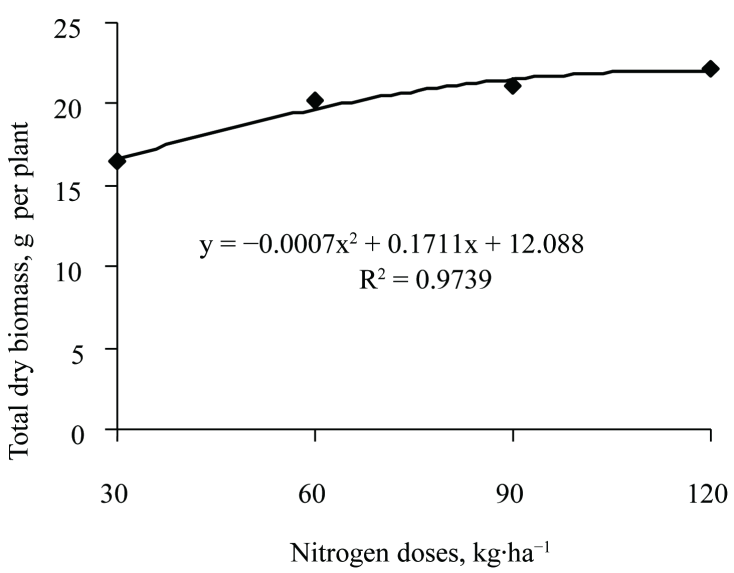

(b)

Figure 3. Number of grains per plant (NGP) (a) and total dry biomass (TDB); (b) of crambe as a function of increasing doses of $\mathrm{N}$. 
Potassium fertilization did not significantly affect any of the evaluated production parameters. However, when the regression of the data was performed, the results of NGP were significant at 5\% probability and relevant to the linear trend; however, it can be seen that increasing $\mathrm{K}$ rates, from 50 to $125 \mathrm{~kg} \cdot \mathrm{ha}^{-1}$ only caused a $12.88 \%$ increase in the NGP (Figure 4).

According [17], one of the treatments that have contributed least to the increase in productivity crambe grain was potassium individually. Likewise, [16] evaluated the isolated effect of N, P and K on the yield of crambe plants in an experiment conducted in the field and the fertilization with $\mathrm{N}$ and $\mathrm{K}$ allowed the increase in crambe yields. However, [19] state that the productivity of crambe grain was limited to the low K contents in the soil. According to the authors, the low $\mathrm{K}$ availability in the soil $\left(<30 \mathrm{mg} \cdot \mathrm{dm}^{-3} \mathrm{~K}\right)$ influenced to the productivity ofcrambe grains less than $30 \%$ of maximum productivity.

The combination of nitrogen with potassium significantly influenced the mass of a thousand grains at $1 \%$ and $5 \%$ of probability with the addition of $50 \mathrm{~kg} \cdot \mathrm{ha}^{-1}$ and $125 \mathrm{~kg} \cdot \mathrm{ha}^{-1}$ of potassium, respectively (Figure 5), where the highest values were obtained for $125 \mathrm{~kg} \mathrm{~K} \mathrm{ha}^{-1}$

In the unfolding interaction it was observed that the levels of nitrogen 30 and $90 \mathrm{~kg} \cdot \mathrm{ha}^{-1}$ influenced the thousand grain weight significantly at the level of $5 \%$ probability in relation to potassium (Figure 6).

According to the regression analysis of interaction data, there was significance at $1 \%$ of probability for the number of grains per plant when the $\mathrm{N}$ was applied with increasing doses of $\mathrm{K}$, except for the higher dose of 125 $\mathrm{kg} \cdot \mathrm{ha}^{-1}$, which presented significance level of $5 \%$ probability (Figure 7).

According [17], although there was no significant difference between treatments, the arrangement between nitrogen and potassium was the one that most contributed to increased productivity.

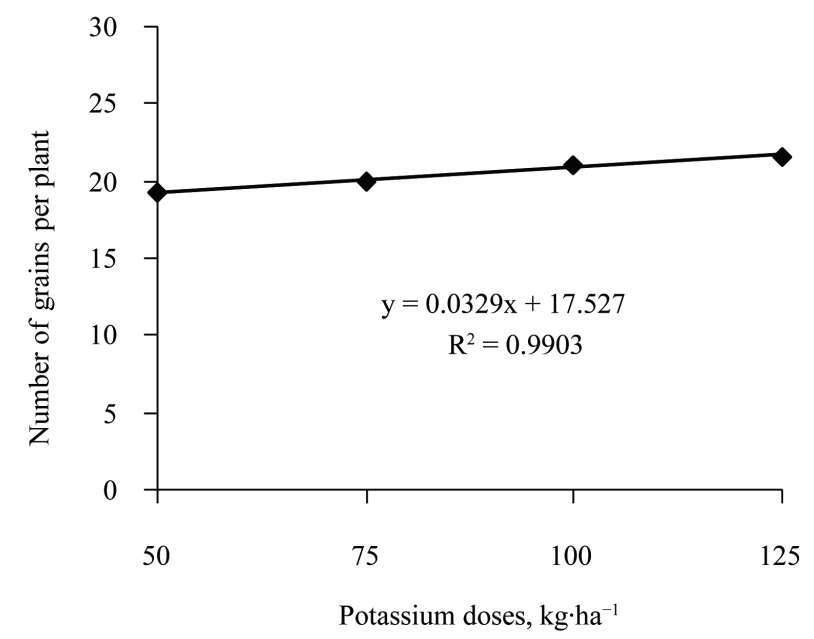

Figure 4. Number of grains per plant (NGP) of crambe as a function of increasing doses of K.

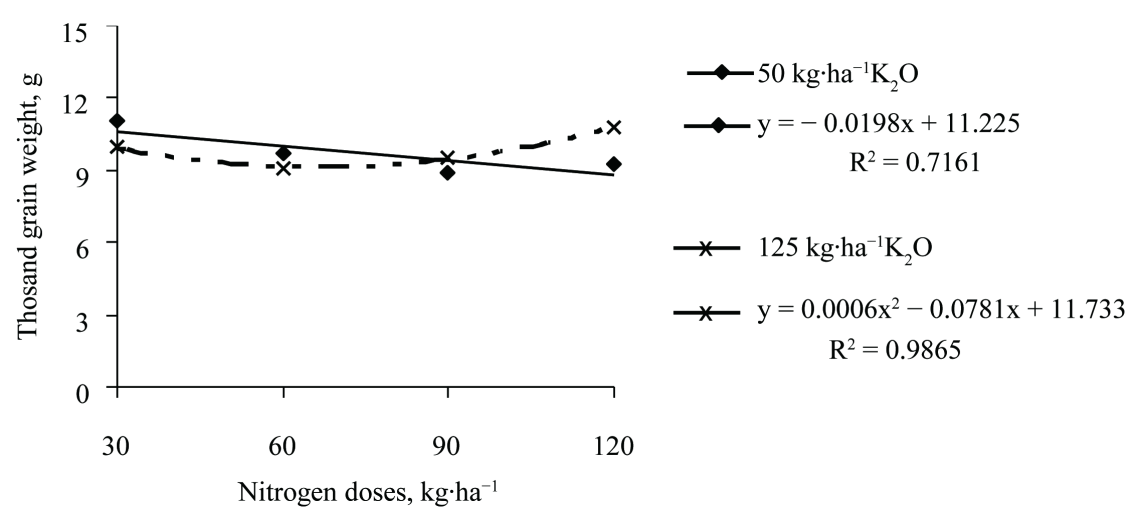

Figure 5. Thousand grain mass (TGM) in function of $\mathrm{N}$ rates considering applying $50 \mathrm{~kg} \cdot \mathrm{ha}^{-1}$ and $125 \mathrm{~kg} \cdot \mathrm{ha}^{-1}$ of $\mathrm{K}$. 

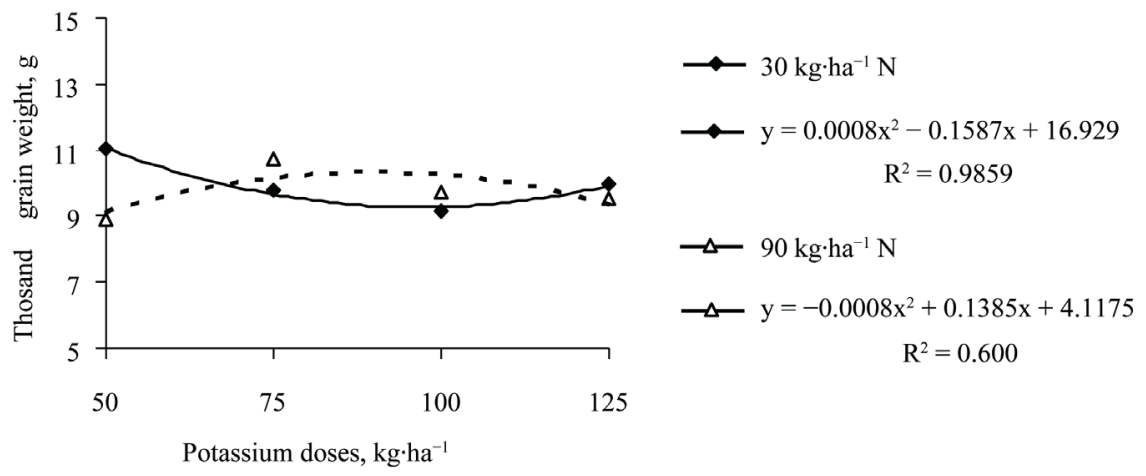

Potassium doses, $\mathrm{kg} \cdot \mathrm{ha}^{-1}$

Figure 6. Thousand grain mass (TGM) for the use of K considering applying $30 \mathrm{~kg} \cdot \mathrm{ha}^{-1}$ and $90 \mathrm{~kg} \cdot \mathrm{ha}^{-1} \mathrm{of} \mathrm{N}$.

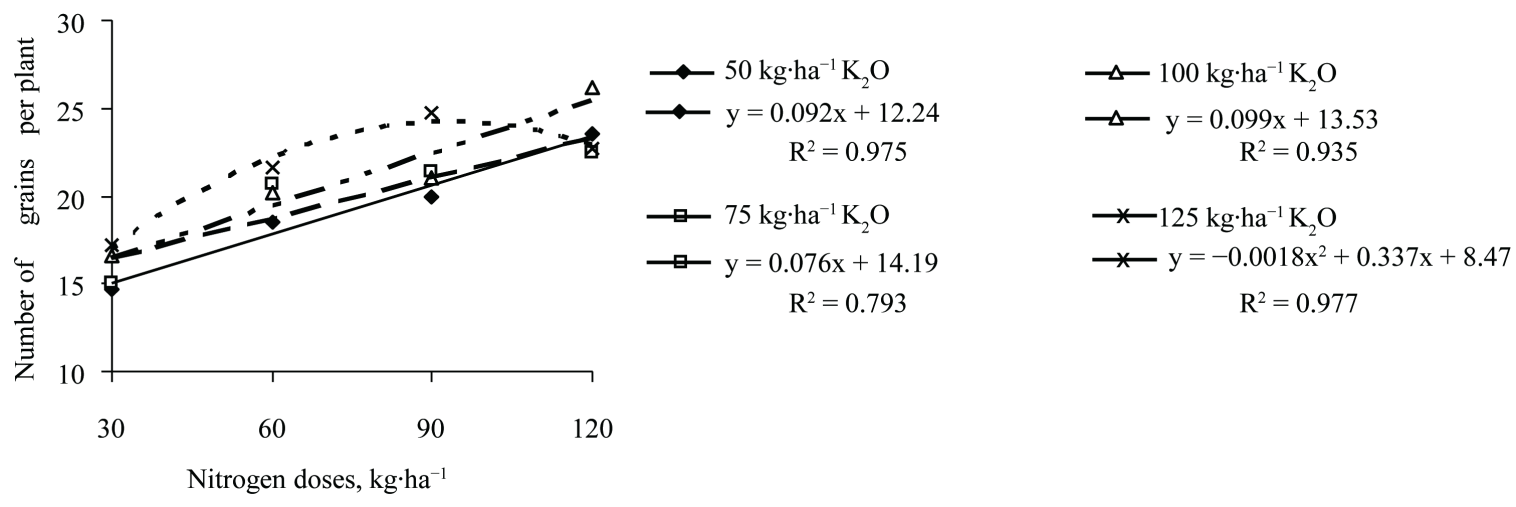

Figure 7. Number of grains per plant (NGP) as a function of the use of N, considering the application of increasing Krates.

It is also observed for the regression of the data, that when $\mathrm{N}$ was added to the lower dose of $\mathrm{K}$, it did not cause significant effect on the total dry biomass of crambe. For the other Krates with the $\mathrm{N}$, significance was observed at $1 \%$ of probability (Figure 8 ).

The authors [20] found that the rates of application between 50 and $70 \mathrm{~kg} \cdot \mathrm{ha}^{-1}$ of $\mathrm{K}_{2} \mathrm{O}$ maintained the canola productivity at adequate levels.

The effect of $\mathrm{K}$ used at a nitrogen rate of $90 \mathrm{~kg} \cdot \mathrm{ha}^{-1}$ presented significance at $5 \%$ probability for NGP and TDB (Figure 9).

No significance was observed by comparing the treatments with the control. However, when the regression of the data was done it was observed significant effect at $1 \%$ of probability for the number of grains per plant and total dry biomass of crambe. The crambe plants grown with higher doses of nitrogen and potassium reached number of grains per plant index and total dry biomass, respectively $144 \%$ and $67 \%$ higher, compared to the control.

The authors [21] observed an increase in productivity of crambe with the addition of $12 \% \mathrm{~N}$ on average with a dose of $20 \mathrm{~kg} \cdot \mathrm{ha}^{-1}$, and $28 \%$ with a dose of $40 \mathrm{~kg} \cdot \mathrm{ha}^{-1}$ compared with the control.

This increase also was evidenced by [22] in an experiment with plants subjected to a lack of $\mathrm{N}$ in the solution. These plants were capable of producing only $5.18 \%$ of biomass compared to those grown with $\mathrm{N}$, while the plants carried out under K deficiency conditions were capable of producing the equivalent quantity of $40.43 \%$ of the biomass accumulated by the plant to supply this appropriate nutrient.

It is worth of noting that the thousand grain mass presented the highest values for the combination of $120 \mathrm{~kg}$ $\mathrm{N} \mathrm{ha}^{-1}$ with $125 \mathrm{~kg} \mathrm{~K} \mathrm{ha}^{-1}$ (Figure 5). Comparing these values with those ones presented for total dry biomass of crambe (Figure 8), can realize that the same combination, i.e., $120 \mathrm{~kg} \mathrm{~N} \mathrm{ha}^{-1}$ with $125 \mathrm{~kg} \mathrm{~K} \mathrm{ha}^{-1}$, caused the highest value for total dry biomass.].

Nitrogen is usually the required element in largest quantity by plants [13]. When plants are deficient in this element, they have leaves with pale-green coloration and yellow. Nitrogen is necessary for synthesis of chlorophyll and as part of this molecule, is involved in photosynthesis [23]. In the absence of supplied nitrogen to the 


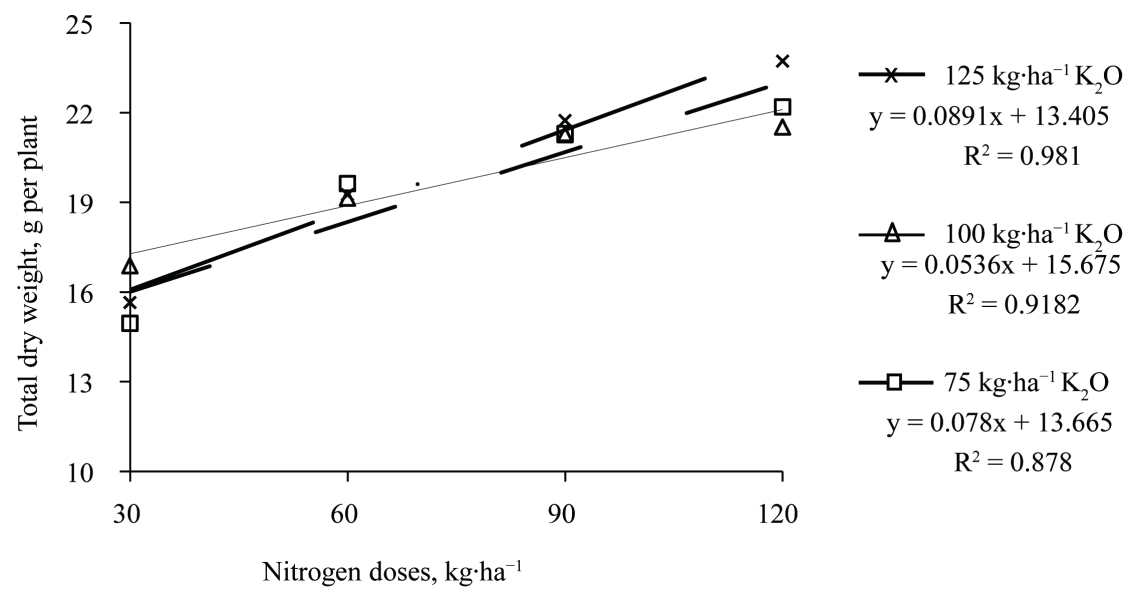

Figure 8. Total dry biomass (TDB) of crambe plants in function of $\mathrm{N}$ and the doses 75 , 100 and $125 \mathrm{~kg} \cdot \mathrm{ha}^{-1}$ of $\mathrm{K}$.

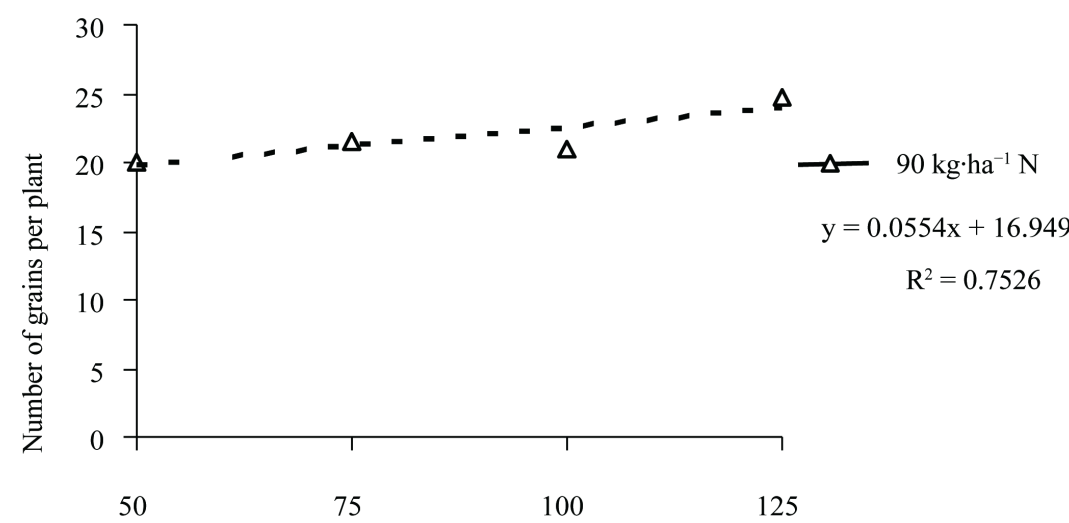

Potassium doses, $\mathrm{kg} \cdot \mathrm{ha}^{-1}$

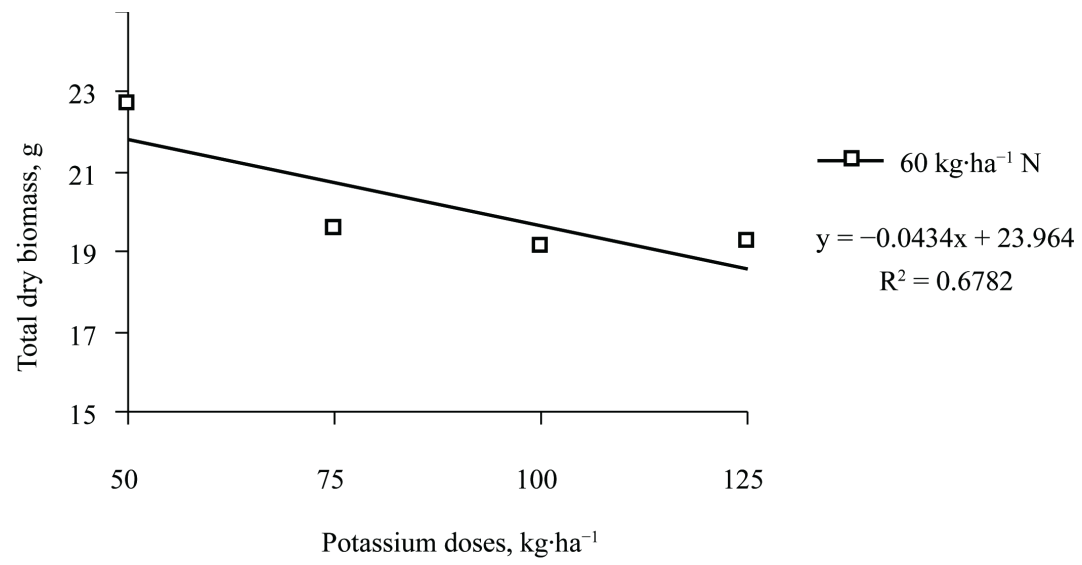

Figure 9. Number of grains per plant (NGP) and total dry biomass (TDB)as a function of the use of $\mathrm{K}$, considering the application of $90 \mathrm{~kg} \cdot \mathrm{ha}^{-1}$ of $\mathrm{N}$.

soil, the plant degrades the chlorophyll molecule, and nitrogen takes place in regions of active growth, where it performs it is functions. Thus persisting $\mathrm{N}$ deficiency, there is a reduction in chlorophyll content, the plants will not use sunlight as an energy source to carry out essential functions such as other nutrients absorption and carbohydrates for their growth and development [24]. Besides nitrogen, the use of potassium influences seed yields 
and seed oil contents. Plants have a demand for K in order to maintain a high nutrient content in the cell cytoplasm, which ensures enzymatic activity [25].

\section{Conclusions}

Using nitrogen caused an increase in the number of crambe branches.

The increase in the number of grains per plant and total dry biomass was directly proportional to the use of increasing doses of nitrogen and potassium.

The combination of $120 \mathrm{~kg} \mathrm{~N} \mathrm{ha}^{-1}$ with $125 \mathrm{~kg} \mathrm{~K} \mathrm{ha}^{-1}$ was the one that resulted in a better crambe yield for this study.

\section{References}

[1] Ferrari, R.A., Oliveira, V.S. and Scabio, O.A. (2005) Biodiesel from Soybean: Characterization and Consumption in an Energy Generator. Química Nova, 28, 19-23. http://dx.doi.org/10.1590/S0100-40422005000100004

[2] Oliveira, F.C.C., Suarez, P.A.Z. and Santos, W.L.P. (2008) Biodiesel: Possibilidades e desafios. Química Nova na Escola, 28, 3-8. http://qnesc.sbq.org.br/online/qnesc28/02-QS-1707.pdf

[3] BNDES, Banco Nacional do Desenvolvimento (2008) Bioetanol de cana-de-açúcar: Energia para o desenvolvimento sustentável. BNDES e CGEE, Rio de Janeiro, 316. http://www.cgee.org.br/atividades/redirect.php?idProduto=5126

[4] Echevenguá, A. (2007) Crambe surge como nova opção para produzir biodiesel. Instituto Eco \& Ação. www.ecoeacao.com.br

[5] Oliva, A.C.E. (2010) Qualidade de sementes de crambe submetidas a métodos de secagem e períodos de armazenamento. MSc. Dissertation, Universidade Estadual Paulista, SP.

[6] Baez, O. (2007) Crambe a grande aposta das pesquisas em Mato Grosso do Sul. Pantanal News. http://www.biodieselbr.com/noticias/em-foco/crambe-grande-aposta-pesquisas-mato-grosso-sul.htm

[7] Jasper, P.A., Biaggioni, M.A.M., Silva, P.R.A., Seki, A.S. and Bueno, C.O. (2010) Analysis of Energy in the Crambe Culture (Crambe abyssinica Hochst) Produced in No Tillage. Engenharia Agrícola, Jaboticabal, 30, 395-403. http://www.scielo.br/pdf/eagri/v30n3/04.pdf

[8] EMBRAPA, Empresa Brasileira de Pesquisa Agropecuária (2006) Sistema brasileiro de classificação de solos. 2nd Edition, Centro Nacional de Pesquisa de Solos, Rio de Janeiro.

[9] Ferreira, D.F. (2009) Estatística básica. 2nd Edition, UFLA, Lavras.

[10] Gomes, P.F. and Garcia, C.H. (2002) Estatística aplicada a experimentos agronômicos e florestais—Exposição com exemplos e orientações para uso de aplicativos. FEALQ, Piracicaba.

[11] Freitas, M.E. (2010) Comportamento Agronômico da cultura do Crambe (Crambe abyssinica Hochst) em função do manejo empregado. MSc. Dissertation, Universidade Federal da Grande Dourados, Dourados.

[12] Vechiatto, C.D. and Fernandes, F.C.S. (2011) Effects of Nitrogen on Doses in Crambe Culture Coverage. Revista Cultivando o Saber, 4, 18-24.

[13] Malavolta, E., Vitti, G.C. and Oliveira, S.A. (1997) Avaliação do estado nutricional das plantas: Princípios e aplicações. 2nd Edition, Potafos, Piracicaba.

[14] Castro, C. and Oliveira, F.A. (2005) Nutrição e adubação do girassol. In: Leite, R.M.V.B., Brighenti, A.M. and Castro, C., Eds., Girassol no Brasil, Londrina, Embrapa Soja, 317-373.

[15] Viana, O.H. (2013) Cultivo de crambe na região oeste do Paraná. MSc. Dissertation, Universidade Estadual do Oeste do Paraná, Cascavel.

[16] Pitol, C., Broch, D.L. and Roscoe, R. (2010) Tecnologia e Produção: Crambe. Fundação MS, Maracaju.

[17] Lunelli, I.E. (2012) Efeitos de arranjos nutricionais de NPK na produtividade de grãos e rendimento de óleo da cultura do crambe. MSc. Dissertation, Universidade Estadual do Oeste do Paraná, Cascavel.

[18] Camargo, F.P., Larazini, E., Pina, M.S., Oliveira, W.A.S. and Daniel, H. (2012) Influência da adubação de semeadura na massa seca e no acúmulo de micronutrientes em plantas de Crambe (Crambe abyssinica Hoechst). 6th Congresso Internacional de Bioenergia, Curitiba.

[19] Martins, R.S, Gabriel, V.W., Honorato, G.Z., Vieira, J.C.M., Garcia, E.A.V., Silva, F.E. and Steiner, F. (2013) Adubação potássica residual para a Cultura do crambe. 12th Congresso de Iniciação Científica, Faculdades Integradas de Ourinhos-FIO/FEMM.

[20] Ávila, M.R., Braccini, A.L., Scapim, C.A. and Albrecht, L.P. (2004) Potassium Fertilization and Its Effect on the Yield and Physiological and Sanitary Quality of Canola Seeds. Acta Scientiarum. Agronomy, 26, 475-481. 
[21] Moreira, M.A., Alves, J.M., Lima L.E., Freitas, A.R., Cabral, P.H.R. and Teixeira, M.B. (2010) Produção e teor de óleo de crambe em função da saturação por bases e adubação mineral NPK. 4th Congresso da rede brasileira de tecnologia de biodiesel; 7th Congresso brasileiro de plantas oleaginosas, óleos, gorduras e biodiesel. Anais, Belo Horizonte.

[22] Colodetti, T.V., Rodrigues, W.N., Christo, L.F., Martins, L.D. and Tomaz, M.A. (2013) Biomass Loss Caused by Deficiency of Macronutrients in Crambe abyssinica. Enciclopédia Biosfera, 9, 2027-2038.

[23] Epstein, E. and Bloom, A.J. (2006) Nutrição mineral de plantas: Princípios e perspectivas. Londrina, Editora Planta. http://www.editoraplanta.com.br/demoNM.pdf

[24] Silva, T.R.B., Reis, A.C.S. and Maciel, G.C.D. (2012) Relationship between Chlorophyll Meter Readings and Total N in Crambe Leaves as Affected by Nitrogen Topdressing. Industrial Crops and Products, 39, 135-138. http://www.sciencedirect.com/science/article/pii/S0926669012000878?np=y\# http://dx.doi.org/10.1016/j.indcrop.2012.02.008

[25] Santos, J.I., Silva, T.R.B., Rogerio, F., Santos, R.F. and Secco, D. (2013) Yield Response in Crambe to Potassium Fertilizer. Industrial Crops and Products, 43, 297-300. http://dx.doi.org/10.1016/j.indcrop.2012.07.043 